\title{
Clinical and epidemiological profile of ocular emergencies in large teaching hospital
}

\section{Perfil clínico y epidemiológico de las urgencias oftalmológicaș en la sala de emergencias de un hospital universitario}

\author{
Mariana Cabrera-Pérez*, Mª Alejandra Martínez-Ceballos and Natalia Cáceres-Duque
}

Department of Ophthalmology, Fundación Cardioinfantil, Bogotá, Colombia

\begin{abstract}
Purpose: The purpose of the study was to characterize emergency room (ER) ophthalmology referrals to identify the most common pathologies, the frequency of urgent and non-urgent diagnoses, and compare diagnostic accuracy between the ER physician and the ophthalmologist. Methods: Cross-sectional study, we included consecutive patients referred to the ophthalmology department from the ER of a large general teaching hospital in Bogotá, Colombia,from November 1,2016, to April 30,2017. Variables extracted from the patients' medical records included age, sex, type of insurance, cause (traumatic vs. nontraümatic), referring physician's diagnosis, final diagnosis, and urgency (urgent, semi-urgent, or non-urgent). Results: A total of 473 patients were included in this study. $52.9 \%$ of visits were for an urgent condition, $17.1 \%$ were considered semi-urgent, and $30 \%$ of the visits were not urgent. The most common diagnosis was a corneal foreign body (22.4\%), often from a work-related accident. Urgent or semi-urgent visits and traumatic injuries were more frequent in males and in patients with jöb insurance $(p<0.01)$. The agreement between the diagnosis given by the ER physician and the ophthalmologist was $34.1 \%$. Conclusions: A much higher prevalence of corneal foreign bodies (22.4\%) was observed compared to the reported global literature, highlighting the urgent need to increase eye protection at work and home. About $30 \%$ of visits were due to non-urgent conditions, which could be decreased by teaching patients and training our nurses in triage to identify true ocular emergencies. ER physicians need more ophthalmology training evidenced by the low agreement between their diaghosis
\end{abstract} and the ophthalmologist's diagnosis.

Key words: Emergency service. Hospital. Public health. Ophthalmology. Eye injuries. Epidemiology.

\section{Resumen}

Objetivo: Identificar las patologías oculares más frecuentes en el servicio de urgencias, categorizar el número de consültas urgentes y no urgentes, evaluar la concordancia diagnóstica entre el médico de urgencias (MU) y el oftalmólogo. Métodos: Estudio observacional analítico de corte transversal. Se incluyeron pacientes que asistieron al servicio de urgencias de un hospital universitario de alto nivel de complejidad en Bogotá, Colombia, por un motivo de consulta oftalmológico desdecêl 1 de noviembre de 2016 al 30 de abril de 2017. Se extrajeron variables sociodemográficas (edad, sexo, aseguradora de săfud), tipo de lesión (traumática/no traumática), clasificación del cuadro clínico (urgente/semiurgente/no urgente), diagnósticō del MU, diagnóstico del oftalmólogo. Resultados: Se analizaron 473 pacientes. El 52.9\% de las visitas fueron de carácter urgènte,

Date of reception: 23-07-2019 Torre I 7, 110131 Bogotá, Colombia

E-mail: marianacab@gmail.com
Date of acceptance: 21-09-2019

DOI: 10.24875/RMOE.M20000092

2604-1731/○ 2020 Sociedad Mexicana de Oftalmologí Published by Permanyer. This is an open acce creativecommons.org/licenses/by-nc-nd/4.0/).

Available online: $02-01-2020$ Rev Mex Oftalmol (Eng). 2020;94(1):12-18 www.rmo.con.m. 
el 17.1\%, semiurgentes y el 30\%, no urgentes. El diagnóstico más frecuente fue de cuerpo extraño corneal (22,4\%), la mayoría de ellos relacionados con accidentes laborales $(p<0.01)$, y el sexo masculino fue el más afectado. El acuerdo diagnóstico entre el MU y el oftalmólogo fue del 34.1\%. Conclusiones: Se encontró una alta prevalencia de cuerpo extriaño corneal comparado con la literatura mundial, lo que evidencia la necesidad de insistir en el uso de protección ocular en casa y en el trabajo. El $30 \%$ de las visitas se consideraron no urgentes, lo que enfatiza la necesidad de informar a loșpacientes y al personal encargado del triage en urgencias para identificar urgencias oftalmológicas verdaderas. La pọbre concordancia en los diagnósticos posiblemente refleja una falta de entrenamiento en oftalmología del personal de urgencias.

Palabras clave: Urgencias médicas. Salud pública. Oftalmología. Servicios de salud ocular. Epidemiología.

\section{Introduction}

The number of emergency room (ER) visits has increased dramatically in the past two decades, not only in Colombia, but in many other countries'. There are few dedicated ophthalmology emergency departments in Bogotá and most patients go to a general hospital if they have an ophthalmic emergency. Treatment in the ER is up to 10 times more expensive than an outpatient appointment ${ }^{2}$ and contributes to long waiting times in crowded ER. Furthermore, many ER consultations are not urgent (around $37 \%$ in general) ${ }^{3}$. In ophthalmology, non-urgent conditions seen at the ER are even more frequent, ranging from $50 \%$ to $80 \%{ }^{4-9}$. The most common non-urgent ER visits are due to conjunctivitis, subconjunctival hemorrhage, and hordeolum $\mathrm{m}^{4,10,11}$. The most common urgent conditions are corneal abrasion, corneal foreign body, and orbital cellulitis ${ }^{4,10}$.

Consequently, to be able to design policies to improve patient care and decrease waiting times, it is crucial to identify the frequency of urgent and non-urgent conditions in our population and the risk factors associated with an ocular emergency.

This study describes the frequency, urgency, and type of ER visits that were referred to the ophthalmology department of a large general hospital in Bogotá, Colombia. We also evaluated the risk factors for an urgent consultationand evaluated the agreementbetween the diagnosis given by the ER physician and the one given by the ophthalmologist.

\section{Methods}

This was a cross-sectional analytic study. The medical records of all consecutive patients who came into the ER of the Fundación Cardioinfantil (a large general teaching hospital in Bogotá, Colombia) and referred for ophthalmic evaluation from November 1, 2016, to April 30, 2017 were reviewed. Ethics approval was obtained from the Institutional Review Board. We estimated a sample size of 320 patients, considering the prevalence of $50 \%$ for non-urgent visits to the $\mathrm{ER}^{4,12,13}$ (10 events per variable for a minimum number of 15 parameters).

The demographic variables evaluated included age, sex, day of visit, and type of health insurance (basic [universal insurance], complementary [higher incōme patients], and job insurance [for job-related conditions]). The cause (traumatic vs. nontraumatic) was also-recorded. The initial diagnosis of the ER physician and of the ophthalmologist was recorded for each patient. Patient outcomes were classified into three categories: (1) treated and discharged, (2) admitted for emergency surgery or treatment, and (3) no treatment required. Ophthalmic diagnoses were categorized as urgent (evaluation by an ophthalmologist within minutes-hours), semi-urgent (can be evaluated by an ophthalmologist within 2-7 days), ornon-urgent(schedulean outpatientappointīient when available), according to a consensus from the ophthalmologists of the department (Table 1).

A multivariate logistic regression analysis was performed to determine demographic factors associated with an urgent/semi-urgent versus a non-urgent diagnosis. Urgent and semi-urgent diagnoses were grouped together in the analysis to include all potentially sight-threatening conditions. Covariates included ăge, sex, and type of insurance (basic, complementary [higher income patients], or work insurance [job-relatedaccidents]). Individuals were categorized by age on the following categories: children (age 0-12), teenagers fage 13-20), adults (age 21-60), and older adults (age 61 years or older), given that the type and etiology of eye conditions differ with age. A separate model was used to determine whether the type of injury (traumatic vs. nontraumatic) was associated with an urgent/ semi-urgent versus non-urgent diagnosis. The mëdel was adjusted for the same covariates listed previouisly.

\section{Results}

A total of 473 patients were included in the analysis of visits made from November 1, 2016, to April 30, 2017. 
Rev Mex Oftalmol (Eng). 2020;94

Table 1. Classification of diagnosis according to urgency

\begin{tabular}{|c|c|c|}
\hline Urgent & Semi-urgent & Non-urgent \\
\hline Immediate evaluation & Evaluation in 2-7 days & Outpatient appointment \\
\hline Moderate-to-severe chemical burn & Mild chemical trauma* & Infectious conjunctivitis \\
\hline Corneal foreign body & Minor blunt trauma ${ }^{+}$ & Subconjunctival hemorrhage \\
\hline Infectious keratitis & Posterior vitreous detachment ${ }^{\wedge}$ & Blepharitis/hordeolum/chalazion \\
\hline Acute glaucoma & Muscle paresis (with otherwise normal exam) & Chronic glaucoma \\
\hline Penetrating ocular trauma & Preseptal orbital cellulitis & Dry eye \\
\hline Uveitis & Herpes zoster ophthalmicus (without keratitis) & Pterygium \\
\hline Optic neuritis/papilledema & & Migraine with ocular pain \\
\hline Moderate-to-severe blunt trauma & & Refractive error/cataract \\
\hline \multicolumn{3}{|l|}{ Retinal detachment } \\
\hline Postseptal orbital cellulitis & & \\
\hline
\end{tabular}

Table 2. Sociodemographic and visit characteristics of patients

\begin{tabular}{|c|c|c|}
\hline Characteristic & \multicolumn{2}{|c|}{ Total } \\
\hline Subjects, $n(\%)$ & 473 & $(100)$ \\
\hline Age, mean (SD), years & 40.9 & (17.7) \\
\hline $\begin{array}{l}\text { Gender, n (\%) } \\
\text { Male } \\
\text { Female }\end{array}$ & $\begin{array}{l}301 \\
172\end{array}$ & $\begin{array}{l}(63.6) \\
(36.4)\end{array}$ \\
\hline $\begin{array}{l}\text { Visit urgency, n (\%) } \\
\text { Urgent } \\
\text { Semi-urgent } \\
\text { Non-urgent }\end{array}$ & $\begin{array}{c}250 \\
81 \\
142\end{array}$ & $\begin{array}{c}(52.9) \\
(17.1) \\
(30)\end{array}$ \\
\hline $\begin{array}{l}\text { Type of injury, } \mathrm{n}(\%) \\
\text { Traumatic } \\
\text { Nontraumatic }\end{array}$ & $\begin{array}{l}210 \\
263\end{array}$ & $\begin{array}{l}(44.4) \\
(55.6)\end{array}$ \\
\hline $\begin{array}{l}\text { Day of visit, n (\%) } \\
\text { Monday } \\
\text { Tuesday } \\
\text { Wednesday } \\
\text { Thursday } \\
\text { Friday } \\
\text { Saturday } \\
\text { Sunday }\end{array}$ & $\begin{array}{c}91 \\
110 \\
79 \\
62 \\
83 \\
37 \\
11\end{array}$ & $\begin{array}{l}(19.2) \\
(23.3) \\
(16.7) \\
(13.1) \\
(17.5) \\
(7.8) \\
(2.3)\end{array}$ \\
\hline $\begin{array}{l}\text { Insurance type, } \mathrm{n}(\%) \\
\text { Basic } \\
\text { Complementary } \\
\text { Work }\end{array}$ & $\begin{array}{c}350 \\
53 \\
70\end{array}$ & $\begin{array}{l}(74 .) \\
(11.2) \\
(14.8)\end{array}$ \\
\hline $\begin{array}{l}\text { Patient outcomes, } \mathrm{n}(\%) \\
\text { Treated and discharged } \\
\text { Admission for surgery/treatment } \\
\text { No treatment required }\end{array}$ & $\begin{array}{c}393 \\
50 \\
30\end{array}$ & $\begin{array}{c}(83.1) \\
(10.6) \\
(6.3)\end{array}$ \\
\hline
\end{tabular}

Table 2 shows the demographic and visit characteristic sof the patients. The mean age at presentation was $40.9 \pm 17.7$ and $64 \%$ of patients were male. Monday and Tuesday were the days with the highest frequency of visits (19.2\% and $23.3 \%$, respectively). About $74 \%$ of patients came in with basic health coverage, $11.2 \%$ with complementary insurance, and $14.8 \%$ with work insurance. Traumatic eye injuries accounted for $44.4 \%$ of all consults; $80 \%$ of these patients were male and the average age was $36.3 \pm 13.8$. About $83 \%(83.1 \%)$ of patients were discharged after treatment, $10.6 \%$ were admitted for surgery or treatment, and $6.3 \%$ required no treatment (either the exam was normal or the-condition was self-limited without treatment).

Around $52.9 \%$ of patients had an urgent ophthatimic condition, $17.1 \%$ were considered semi-urgent, and $30 \%$ were non-urgent. Non-urgent consultations were more common among the $0-12(40 \%)$ and $>60(42.7 \%)$ age groups compared to patients aged 13-60 (27\%), although this difference was not statistically significant. The results of a multivariate logistic regression môdel (Table 3) showed that urgent or semi-urgent visits were more frequent among males odds ratio (OR: $2.06 ; \overline{\overline{9}} 5 \%$ confidence interval [Cl]: $1.36-3.13)$ and patients with work insurance (OR: 3.99; 95\% Cl: 1.76-9.06). Similarly, traumatic injuries were more frequent in males (OR: 3.46; 95\% IC: 2.01-5.94) and in patients with work insurance (OR: 6.56; 95\% Cl 1.82-23.7). 
M. Cabrera-Pérez, et al.: A clinical and epidemiological profile of ophthalmic copsults

Table 3. Multivariate logistic regression analysis of factors associated with ER visits that were urgent/semi-urgent or traumatic/nontraumatic

\begin{tabular}{|c|c|c|c|c|c|c|c|c|c|c|c|c|c|}
\hline \multirow{4}{*}{$\begin{array}{l}\text { Variables } \\
\text { Total }\end{array}$} & \multicolumn{12}{|c|}{ Number of subjects, (\%) } & $\stackrel{1}{2}$ \\
\hline & \multicolumn{6}{|c|}{ Visit urgency } & \multicolumn{6}{|c|}{ Type of injury } & हू \\
\hline & \multicolumn{2}{|c|}{ Urgent/semi-urgent } & \multicolumn{2}{|c|}{ Non-urgent } & \multicolumn{2}{|c|}{ OR (95\% CI) } & \multicolumn{2}{|c|}{ Traumatic } & \multicolumn{2}{|c|}{ Nontraumatic } & \multicolumn{2}{|c|}{ OR $195 \%$} & (A) \\
\hline & 331 & $(70.0)$ & 142 & $(30.0)$ & & & 210 & $(44.4)$ & 263 & $(55.6)$ & & & (C) \\
\hline $\begin{array}{l}\text { Age groups, years } \\
\text { Reference: } 21-60\end{array}$ & 257 & $(73.0)$ & 95 & $(27.0)$ & & & 180 & (51.1) & 172 & $(48.9)$ & & & $\stackrel{\check{U}}{\check{c}}$ \\
\hline $0-12$ & 12 & $(60.0)$ & 8 & $(40.0)$ & 0.6 & $(0.23-1.57)$ & 5 & $(25.0)$ & 15 & $(75.0)$ & 0.44 & 10.1 & $12-[611$ \\
\hline $13-20$ & 19 & $(73.1)$ & 7 & $(26.9)$ & 1.1 & $(0.42-2.70)$ & 12 & $(46.2)$ & 14 & (53.8) & 0.73 & 10.2 & $27-2.24)$ \\
\hline$>60$ & 43 & (57.3) & 32 & (42.7) & 0.59 & $(0.35-1.01)$ & 13 & $(17.3)$ & 62 & (82.7) & 0.23 & & $|1-0.49|$ \\
\hline Gender & & & & & & & & & & & & & $\frac{c}{+}$ \\
\hline $\begin{array}{l}\text { Reterence: remale } \\
\text { Male }\end{array}$ & 231 & $\begin{array}{l}(58.1) \\
(76.7)\end{array}$ & $\begin{array}{l}12 \\
70\end{array}$ & $\begin{array}{l}(41.9) \\
(23.3)\end{array}$ & 2.06 & $(1.36-3.13)$ & $\begin{array}{c}42 \\
168\end{array}$ & $\begin{array}{l}(24.4) \\
(55.8)\end{array}$ & 133 & $\begin{array}{l}(/ 5.6) \\
(44.2)\end{array}$ & 3.46 & & $1-5.94)$ \\
\hline Insurer & & & & & & & & & & & & & $\frac{0}{\sqrt{n}}$ \\
\hline Reference: Basic & 237 & $(67.7)$ & 113 & (32.3) & & & 132 & $(37.7)$ & 218 & $(62.3)$ & & & \\
\hline Complementary & 31 & $(58.5)$ & 22 & (41.5) & 0.75 & $(0.41-1.37)$ & 19 & $(35.9)$ & 34 & $(64.2)$ & 0.7 & 10.3 & $31-1.59)$ \\
\hline Work related & 63 & $(90.0)$ & 7 & $(10.0)$ & 3.99 & $(1.76-9.06)$ & 59 & (84.3) & 11 & (15.7) & 6.56 & 11.8 & $32-23.7)$ \\
\hline
\end{tabular}

OR: Odds ratio; $\mathrm{Cl}$ : Confidence interval.

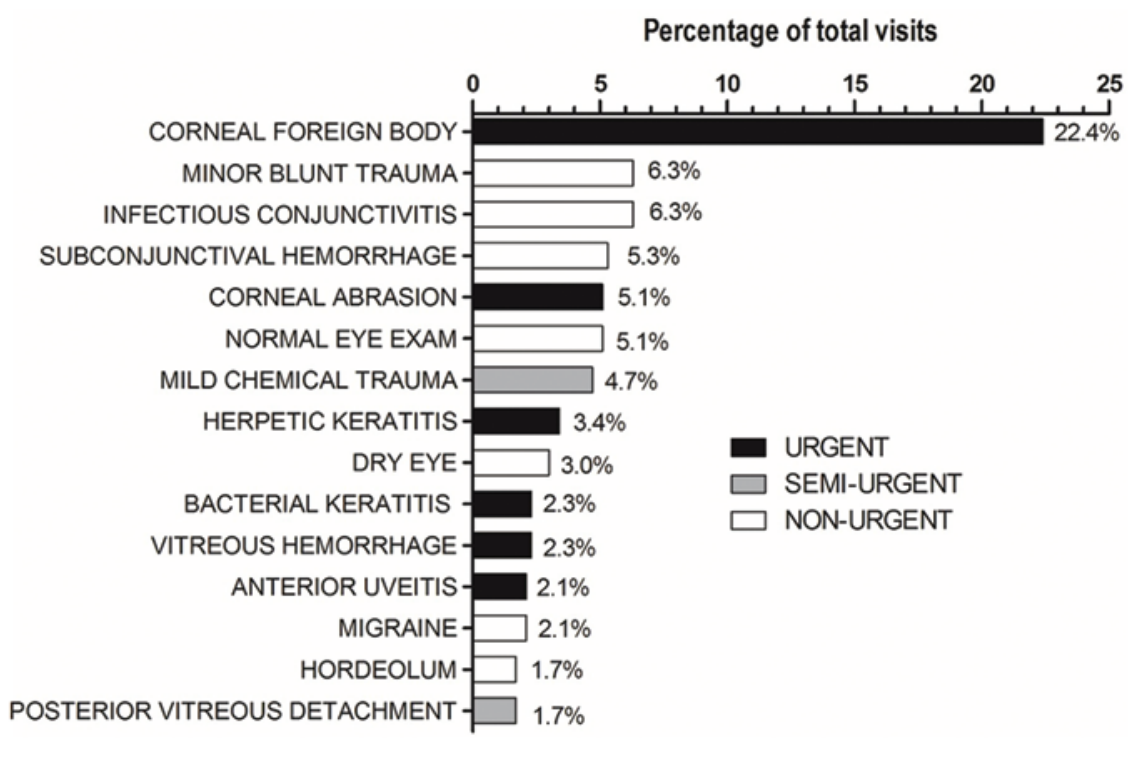

Figure 1. Most common ophthalmic diagnoses.

Figure 1 shows the 15 most common diagnoses classified by urgency. The most common diagnosis was a corneal foreign body $(22.4 \%)$, usually secondary to a job-related accident. The second, third, and fourth most common diagnoses were non-urgent diagnoses such as minor ocular trauma, infectious conjunctivitis, and subconjunctival hemorrhage $(6.3 \%, 6.3 \%$, and $5.1 \%$, respectively). In the fifth place were corneal abrasions
(5.1\%), also a frequent job-related accident. In $5.1 \%$ of patients, the ophthalmic examination was unremarkable, and the patient required no treatment.

Table 4 shows the 10 most frequent diagnoses recorded by the ER physicians and their agreement withothe ophthalmologist's diagnosis. It was difficult to directly compare accuracy of diagnoses given that the diagnosis provided by the ER physician was often nonspecific 
Table 4. Agreement between the 10 most frequent diagnoses recorded by the ER physician and the diagnosis recorded by the ophthalmologist

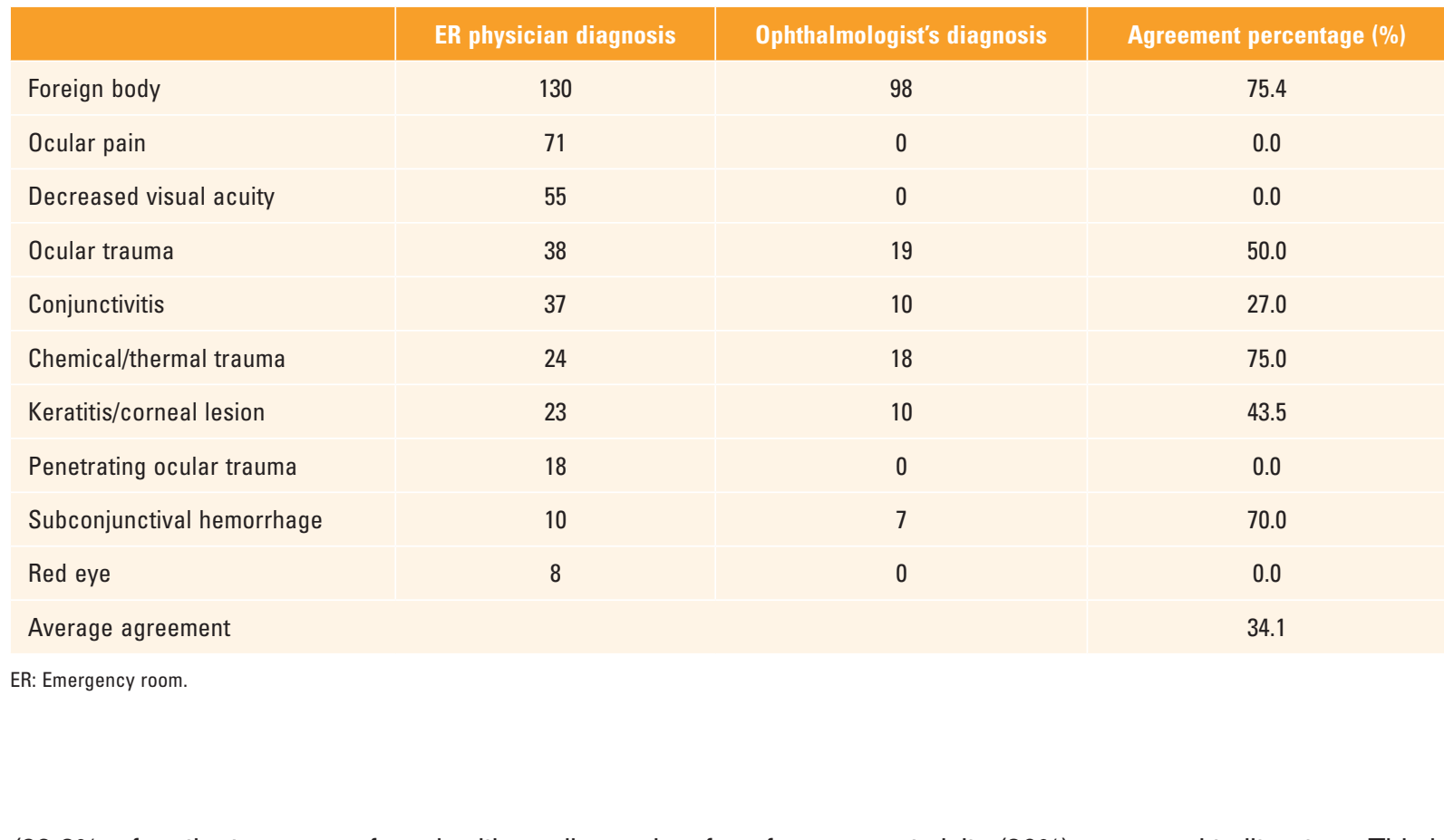

(28.3\% of patients were referred with a diagnosis of "ocular pain," "decreased visual acuity," and "red eye"). Overall, the diagnosis coincided in $34.1 \%$ of cases. The most frequent ER physician diagnosis was "foreign body" in 130 cases (75.4\% agreement). Twenty-five patients were diagnosed in the ER with a penetrating eye injury or acute glaucoma, but none had the condition. In contrast, the eight patients who did have a penetrating injury or acute glaucoma had a different initial diagnosis.

\section{Discussion}

In Bogotá, as in most of the world, emergency services are overcrowded ${ }^{14}$. It is estimated that up to a third part of the visits to emergency departments in Bogotá do not constitute a real emergency ${ }^{15}$, but they spend significant human and physical ER resources. In our cohort, urgent conditions constituted $52.9 \%$ of all visits, $17.1 \%$ were semi-urgent, and non-urgent conditions accounted for $30 \%$ of all visits. A study evaluating almost 12 million ophthalmic ER visits in the US, categorized $44.3 \%$ of visits as non-urgent ${ }^{4}$. In Ireland, Fenton et al. ${ }^{6}$ reported that $80.9 \%$ of visits were non-urgent and Alotaibi et al..$^{13}$ from Saudi Arabia reported that $50.4 \%$ of visits were non-urgent (dry eye, chalazion, blepharitis, and allergic conjunctivitis). In Latin America, a series in Brazi ${ }^{16}$ reported that $55 \%$ of eye-related visits were considered non-urgent and in $\mathrm{Cuba}^{17}, 70.9 \%$ were considered non-urgent. Our series reported a lower percentage of non-urgent visits (30\%) compared to literature. This is partly due to a lower prevalence of infectious conjunnctivitis $(6.3 \%)$ and eyelid inflammation $(1.7 \%)$ in our sample compared to other series (8.7-39.2\%) $4,16,18$. A likely-explanation for this may be that patients with symptoms of conjunctivitis are treated by their primary care physician or they self-medicate (a very common practice in our country).

We reported a very high prevalence of urgent conditions $(52.9 \%)$ which is largely due to the high frequency of corneal foreign bodies observed in our series $(22.4 \%)$ compared to global literature $\left(1.9 \%\right.$ in Egypt ${ }^{5}, 4.5 \%$ in Australia $^{19}, 4.7 \%$ in Saudi Arabia ${ }^{13}, 7.5 \%$ in the US 4 , and $9.3 \%$ in Ireland ${ }^{6}$ ). Our hospital is a referral centeb for many job-related health insurers and this may explain the high prevalence of corneal foreign bodies. At the sâme time, it highlights the frequency of traumatic eye injurjes, especially job-related ones. In our series, $44.4 \%$ of visits were due to traumatic conditions and $28 \%$ of which were admitted with work insurance. This is similar to reports from Italy ${ }^{20}$ and Finland ${ }^{21}$ where $29.6 \%$ and $34 \%$ of eye injuries, respectively, occurred at work. In our series, most of the corneal foreign bodies were diagnosed in welders. This is an avoidable accident if widespread use of eye protection was enforced in work settings. The percentage of job-related eye injuries is probably underestimated in this study because many workers do not have formal work insurance. As expected, the multivariate analysis revealed that being male (most weldersare 
male) and having work insurance was significantly associated with an urgent and traumatic eye injury.

Regarding patient outcomes, $89.4 \%$ of patients were either treated and discharged or required no treatment. The remaining $10.6 \%$ were admitted for surgery or management by another specialty. This means that almost $90 \%$ of the ophthalmic emergencies in this series could potentially be managed either by a primary care physician or be examined in an outpatient setting. A new system needs to be implemented in order to direct these patients to outpatient facilities to free up much needed ER resources for life-threatening emergencies.

In this series, the ER physicians who first attended the patients referred them to the ophthalmology department with a preliminary diagnosis. The diagnosis agreement between the ER physician and the ophthalmologist was low (34.1\%). This discrepancy can be partly explained by the fact that the ER physician does not need to commit to diagnosis as the patient will be examined by an ophthalmologist anyway. However, it does point toward a lack of training in ophthalmology for ER physicians. This is especially evident in the fact that from the 8 patients who had a real ophthalmic emergency (acute glaucoma or penetrating eye injury) and the agreement between the ER physician and the ophthalmologist was $0 \%$. A plan has to be created to train ER staff to identify true ophthalmic emergencies, avoid treatment delays and thus improve outcomes.

This study has several limitations. It is a snapshot of 6 months of the emergency visits and may not reflect all types of visits in our hospital, as insurance contracts vary throughout the year. However, given that the hospital has contracts with over 20 health insurance companies, we believe that the types of conditions may not vary significantly. Like in all retrospective medical record reviews, some information may be missing or incomplete. Not all patients who come in with ocular complaints are evaluated by an ophthalmologist for several reasons (the ophthalmologist is not available at that time; insurance issues or treatment is prescribed by the ER physician). Hence, this series may not be including all patients coming into the ER with ocular complaints. Despite these caveats, it provides valuable information for the hospital to better prepare the ER staff for ophthalmology patients and helps to shed light on the frequency of avoidable job-related eye injuries.

\section{Conclusions}

This is the first report on the frequency and type of urgent ophthalmic referrals from a general ER in Colombia.
Determining the prevalence and type of ophthatmic emergencies is crucial for health planning, decreasing waiting times in the ER, and improving patient care.

Our emergency department is receiving an alarming number of patients with corneal foreign bodies (22:4\%) compared to worldwide literature. The majority of these were job-related and are potentially avoidable with adequate eye protection. Measures need to be taken to ensure eye protection is enforced both at work and home. In addition, we reported a lower prevalence of non-urgent conditions compared to literature, especially regărding conjunctivitis and conditions associated with blepharitis. This needs to be further investigated to determine if these patients are being treated by their primary care physician or if they are self-medicating, as antibiotics can be bought without prescription in our country.

Finally, a large discrepancy was observed between the diagnosis given by the ER physician and the ophthalmologist, especially regarding true ophthatmic emergencies. Better ophthalmology training for ER physicians could lead to more effective management of ER eye-related visits and better outcomes for our patients.

\section{Acknowledgments}

We would like to thank Dr. Rodolfo Dennis and Dr. Erika León, for their contributions to the manuscript.

\section{Conflicts of interest}

The authors declare that there are no conflicts of interest regarding the publication of this article.

\section{Ethical disclosures}

Ethics approval was obtained from the Institutional Review Board. The research adhered to the resolution $8430 / 1993$ of the Health Ministry of Colombia.

Protection of human and animal subjects. The authors declare that no experiments were performed on humans or animals for this study.

Confidentiality of data. The authors declare that they have followed the protocols of their work center on the publication of patient data.

Right to privacy and informed consent. The authors followed the official protocols from their work center:

\section{References}

1. Pines JM, Mullins PM, Cooper JK, Feng LB, Roth KE. National trends in emergency department use, care patterns, and quality of care ofolder adults in the united states. J Am Geriatr Soc. 2013;61:12-7. 
2. Ministerio de Salud y Protección Social. Informe Nacional de Calidad de la Atención en Salud 2015. Bogotá, Colonbia; 2015. Available from: ht tps://www.minsalud.gov.co/sites/rid/Lists/BibliotecaDigital/RIDE/DE/DIJ/ informe-nal-calidad-atencion-salud-2015.pdf.

3. Uscher-Pines L, Pines J, Kellermann A, Gillen E, Mehrotra A. Emergency department visits for nonurgent conditions: systematic literature review. Am J Manag Care. 2013;19:47-59.

4. Channa R, Zafar SN, Canner JK, Haring RS, Schneider EB, Friedman DS, et al. Epidemiology of eye-related emergency department visits. JAMA Ophthalmol. 2016;134:312-9.

5. El-Mekawey HE, Abu El Einen KG, Abdelmaboud M, Khafagy A Eltahawy EM. Epidemiology of ocular emergencies in the egyptian population: a five-year retrospective study. Clin Ophthalmol. 2011;5:955-60.

6. Fenton S, Jackson E, Fenton M. An audit of the ophthalmic division of the accident and emergency department of the royal victoria eye and ear hospital, dublin. Ir Med J. 2001;94:265-6.

7. Jafari AK, Anvari F, Ameri A, Bozorgui S, Shahverdi N. Epidemiology and sociodemographic aspects of ocular traumatic injuries in iran. Int Ophthalmol. 2010;30:691-6.

8. Alangh M, Chaudhary V, McLaughlin C, Chan B, Mullen SJ, Barbosa J, et al. Ophthalmic referrals from emergency wards-a study of cases referred for urgent eye care (The R.E.S.C.U.E study). Can J Ophthalmol. 2016:51:174-9.

9. Domínguez-Serrano F., Molina-Solana P, Infante-Cossío M, Sala-Turrens J, Seva-Silva N, Rodríguez-de-la-Rúa-Franch E. Oftalmología de urgencias. Un estudio epidemiológico: ¿Se utilizan correctamente los recursos? Arch Soc Esp Oftalmol. 2019;94:1-7.

10. Stagg BC, Shah MM, Talwar N, Padovani-Claudio DA, Woodward MA Stein JD, et al. Factors affecting visits to the emergency department for urgent and nonurgent ocular conditions. Ophthalmology. 2017;124:720-9.

11. Vaziri K, Schwartz SG, Flynn HW Jr., Kishor KS, Moshfeghi AA. Eye-related emergency department visits in the United States, 2010. Ophthalmology. 2016;123:917-9.
12. Ivankovic LV, Minaeff TT. Caracterización de las urgencias oftalmelógicas en el hospital josé joaquín aguirre. Rev Hosp Clín Univ Chile 2009; 20:97-102.

13. Alotaibi AG, Osman EA, Allam KH, Abdel-Rahim AM, Abu-Amero KK One month outcome of ocular related emergencies in a tertiary hospital in central saudi arabia. Saudi Med J. 2011;32:1256-60.

14. Zea JH, Posada JS, Piedrahita JJ, Flórez PA. Saturación en los seFicios de urgencias: análisis de cuatro hospitales de Medellín y simulación de estrategias. Gerenc y Políticas Salud 2018;17. Available from: http:// www.revistas.javeriana.edu.co/index.php/gerepolsal/article/view/23135.

15. Rodríguez-Páez FG, Jiménez-Barbosa WG, Palencia-Sánchez F. Uso de los servicios de urgencias en Bogotá, Colombia: un análisis desde el Triaje. Univ y Salud. 2018;20:215. Available from: http://www. reyistas. udenar.edu.co/index.php/usalud/article/view/3562.

16. Almeida H, Fernandes V, Lucena A, Kara-Junior N. Evaluation of thalmic emergencies in a public reference hospital in Pernambuco, Brazil. Rev Bras Oftalmol. 2016;75:18-20.

17. Armengol RA, Castellanos KM, Díaz AG, Borges KR. Incidence of Oeular emergencies in the emergency room of the university general hospital of cienfuegos. MediSur. 2015;13:46-57.

18. Sridhar J, Isom RF, Schiffman JC, Ajuria L, Huang LC, Gologorsky D, et al. Utilization of ophthalmology-specific emergency department Services. Semin Ophthalmol 2018;33:185-90.

19. Kumar NL, Black D, McClellan K. Daytime presentations to a metropolitan ophthalmic emergency department. Clin Exp Ophthalmol. 2005;33:586-92.

20. Gobba F, Dall'Olio E, Modenese A, De Maria M, Campi L, Cavallini GM, et al. Work-related eye injuries: a relevant health problem. main epidemiological data from a highly-industrialized area of northern Italy 9 int $\mathrm{J}$ Environ Res Public Health. 2017;14:E604.

21. Sahraravand A, Haavisto AK, Holopainen JM, Leivo T. Ocular traumas in working age adults in finland helsinki ocular trauma study. Acta Ophthalmol. 2017:95:288-94. 